\title{
Russian Sitcoms: From Post-Soviet Copycats to Aspiring Global Players
}

Jeffrey Brassard ${ }^{1}$

Recibido: 2016-11-21

Enviado a pares: 2016-11-21
Aprobado por pares: 2017-01-11

Aceptado: 2017-02-17

DOI: 10.5294/pacla.2017.20.3.6

Para citar este artículo / to reference this article / para citar este artigo

Brassard, J. (2017). Russian sitcoms: From post soviet copycats to aspiring global players. Palabra Clave, 20(3), 702-721. DOI: 10.5294/pacla.2017.20.3.6

\section{Abstract}

Russian sitcoms have gone through a series of rapid changes since their introduction following the end of the Cold War. The genre was initially met with skepticism in the post-Soviet period. Owing primarily to Russian culture's lack of familiarity with the genre early attempts to localize it failed to attract significant audiences. Only once the television channel STS, with significant help from Sony Pictures Television, began working to bring adapted American sitcoms to Russia did the genre start to resonate with viewers. The first popular sitcom on Russian television was an adaptation of CBS' The Nanny. The success of that series led to the production of numerous other similar programs. Since the early 2000s, Russian sitcoms have proceeded rapidly through three phases: localization, hybridization, and cultural odorlessness. This paper traces the development of the genre by examining three programs: My Fair Nanny, Daddy's Girls and The Kitchen. Each of these programs marks the beginning of a new phase in the development the Russian sitcom from localization, the creation of original Russian series and programs aimed at the global market for formats. The paper also looks at the role that STS and Sony bring the genre to Russia.

1 University of Alberta. Canadá. jrbrassard@ualberta.ca 


\section{Keywords}

Russia; television; sitcom; hybridity; localization (Source: Unesco Thesaurus).

\section{Comedias rusas: de los imitadores post-soviéticos a los aspirantes a jugadores globales}

\section{Resumen}

Las series de comedia rusas han pasado por una serie de cambios rápidos desde su introducción después del fin de la Guerra Fría. El género fue recibido inicialmente con escepticismo en el período post-soviético. Debido principalmente a la falta de familiaridad de la cultura rusa con el género, los primeros intentos por localizarlo no lograron atraer audiencias significativas. Fue solo cuando el canal de televisión STS, con la ayuda de Sony Pictures Television, empezó a trabajar para traer adaptaciones de comedias estadounidenses a Rusia que el género comenzó a resonar con los televidentes. La primera comedia popular en la televisión rusa fue una adaptación del programa The Nanny de CBS. El éxito de esa serie llevó a la producción de muchos otros programas similares. Desde principios de la década del 2000, las comedias rusas han avanzado rápidamente por tres fases: localización, hibridación y ausencia de 'olor' cultural. Este artículo describe el desarrollo del género examinando tres programas: My Fair Nanny, Daddy's Girls y The Kitchen. Cada uno de estos programas marca el inicio de una nueva fase en el desarrollo de la comedia rusa desde la localización, la creación de series originales rusas y programas dirigidos al mercado global de formatos. El artículo también analiza el papel que STS y Sony le dan al género en Rusia.

\section{Palabras clave}

Rusia; televisión; sitcom; hidridación; localización (Fuente: Tesauro de la Unesco). 


\section{Comédias russas: dos imitadores pós-soviéticos aos aspirantes a jogadores globais}

\section{Resumo}

Os seriados cômicos russos têm passado por uma série de mudanças rápidas desde sua introdução após o fim da Guerra Fria. O gênero foi recebido inicialmente com ceticismo no período pós-soviético. Devido principalmente à falta de familiaridade da cultura russa com o gênero, as primeiras tentativas de localizá-lo não conseguiram atingir audiências significativas. Somente depois que o canal de televisão STS, com a ajuda significativa de Sony Pictures Television, começou a trabalhar para trazer adaptações de comédias estadunidenses à Rússia, o gênero começou a ressonar com os telespectadores. A primeira comédia popular na televisão russa foi uma adaptação do programa The Nanny de CBS. O sucesso dessa série levou à produção de muitos outros programas similares. Desde começos do ano 2000, as comédias russas têm avançado rapidamente por três fases: localização, hibridação e ausência de "cheiro cultural". Este artigo descreve o desenvolvimento do gênero examinando três programas: My Fair Nanny, Daddy's Girls e The Kitchen. Cada um destes programas marca o começo de uma nova fase no desenvolvimento da comédia russa desde a localização, a criação de séries originais russas e programas dirigidos ao mercado global de formatos. $\mathrm{O}$ artigo também aborda o papel que STS e Sony dão ao gênero na Rússia.

\section{Palavras-chave}

Rússia; televisão; sitcom; hibridação; localização (Fonte: Tesauro da Unesco). 
Sitcoms were an unknown genre in the Soviet Union and did not appear on Russian television until after the collapse of the communist state in 1991. Dana Heller (2003), in her concise account of the early days of sitcoms in Russia, recounts that, at first, the genre was introduced to Russian audiences in the form of American and British programs, from I Love Lucy to Friends, with Russian voiceovers. Heller also states that early attempts by Russian networks to produce their own sitcoms were not well received. According to her, two of the early post-Soviet sitcoms, Strawberry Café and Family Business, Funny Business, were commercial and critical failures (Heller, 2003). She notes that audiences and critics were particularly troubled by the shallowness of the plots and characters, and baffled by the presence of the laugh-track, an aspect of the genre they believed that even Americans must secretly hate. She ends her piece by noting that, given the relative novelty of the genre, it was possible that Russians merely needed some time to adapt to its conventions. She suggests that "if the sitcom is to be successfully adapted in Russia it will ... need to confront the most fundamental questions concerning Russianness and foreignness" (Heller, 2003, p. 70). She notes that Russians have been able to hybridize Western cultural forms like poetry and the novel and suggest that they might eventually do the same with television genres.

Ultimately, Heller's assertion was correct, and the genre eventually became popular. To better understand the genesis of the Russian sitcom it is necessary to briefly examine the history of the company most responsible for its popularization. Despite the problems with early post-Soviet sitcoms, STS, an entertainment network, worked to popularize the genre. Three of its sitcoms, in particular, have helped the network grow from a relatively small, obscure channel to one of the leading entertainment brands in the former Soviet Union. These three series represent distinct but overlapping phases of the sitcom's growth in Russia: localization, hybridization, and cultural odorlessness. While the stages of the sitcoms' development each have different characteristics and result in very different products, they are all still present on Russian television today. The cultural odorless phase of the Russian sitcom's development is particularly important, as it 
signals Russia's revival as a producer of exportable global culture in a way not seen since the days of the Soviet Union (Roth-Ey, 2011).

\section{The STS Television Channel}

STS Media was founded in 1989, and the station began broadcasting in 1994. By 1996 it had expanded into a national broadcaster that aired primarily licensed Hollywood content. The company began commissioning Russian language content only in 2003 after it hired Alexander Rodanski as general producer ("History of CTC," n.d.). STS is unique among Russian media firms because it was privately owned and controlled until 2015. The majority owner of STS' parent company until an anti-western media law that restricts foreign ownership became law in 2014 was the Modern Times Group, a Stockholm-based media conglomerate, which held approximately forty percent of the shares. ${ }^{2}$ The other major stockholders were National Media Group, a Russian investment group led primarily by Rossiya Bank, which holds about twenty-five percent of the shares and has a blocking vote on the company's board of directors (Tapinas, 2014). The remainder of the company's shares were floated on the NASDAQ until early 2016 when the company delisted its stocks. This stock composition left the company primarily under foreign control, making it unique among the country's six largest broadcasters. Today, STS operates four television channels in Russia (STS, Domashnii, Peretz, and STS Love). It also owns a multinational station available via satellite in Germany, the Baltics, Belarus, Georgia, Azerbaijan, Armenia, Kyrgyzstan, and North America, as well as a channel in Moldova (under the brand STS Mega) and one in Kazakhstan (under the name Channel 31). The station's pace of growth has been remarkable given its late entry into the Russian content market. Ultimately, one cannot speak of STS' emergence as one of Eastern Europe's most prominent entertainment brands without discussing the sitcoms that established the station as a household name.

2 Modern Time Group's ownership share is likely to change as the result of a recent Russian law that limits foreign ownership of Russian media companies to twenty percent. 


\section{The Copycat Nanny and the Beginnings of Post-Soviet Sitcom}

Heller's assertion about the eventual adaptation of Russian audiences to the sitcom genre was prescient. In September of 2004, STS began the Russian sitcom's localization phase with the launch of Moia Prekrasnaia Niania (My Fair Nanny) (Rodnyansky, 2004), an adaptation of the CBS series, The Nanny. The Russian series was a three-way partnership between STS, Sony Television Pictures and Amedia, the production studio where it was filmed. As with most of the series brought to Russia, the Western firm that owned the rights (in this case, Sony), provided consultancy services to Amedia and STS to help them get the production of the series the series underway and to keep the product aligned with the overall transnational The Nanny brand. The plot of the series was essentially a "rags to riches" Cinderella story which, of course, ends with the titular nanny character winning the heart of her wealthy employer. Though there are some minor differences, the Russian version of the program copies its American counterpart very closely. For example, while some of the other international versions of the program recast the nanny's employer, Maxwell Sheffield (named Maxim Shatalin in the Russian version), in another profession, the Russian version of the program leaves him as a successful producer of musical theater. The nanny character, for her part, is recast as a Ukrainian immigrant, named Victoria, but often called by the diminutive Vika. She comes from the working class Moscow suburb of Birulyova. Rather than the eccentricities of New York Jewish culture, the audience sees Ukrainian immigrant slang and Soviet nostalgia (Prokhorova, 2010). For example, in one episode, a Soviet film that features the death of an animal replaces a reference to the American film Bambi, to achieve the same comic effect. In this case, the joke is that the Cici/Zhanna character that serves as the employer's partner is too heartless to have felt sad when an animal died on screen. The series can be understood using Albert Moran's (1998) pie metaphor, which describes how to adapt formatted shows to local tastes. The crust in this metaphor is the structuring elements of the program such as setting, basic character outlines and plot that gives the series its overall shape. The filling is the local cultural norms and humor that allow the audience to enjoy the program within 
their cultural context (Moran, 1998). Thus, the program is an archetypical example of localization.

While other Russian produced sitcoms had failed to resonate, $M y$ Fair Nanny was a commercial success, almost certainly beyond STS' greatest ambitions. Despite the fact that STS' signal still reached fewer Russian households than its competitors, the series managed to become the third highest rated on Russian television (Hutchings \& Rulyova, 2009). Its lead actress, Anastasia Zavarotniuk, quickly rose up the ranks of the Russian star system and became one of the most popular actresses in the country (Hutchings \& Rulyova, 2009). The popularity of the series was such that, even after the Russians had used up the available supply of scripts for the series, they commissioned original scripts that had not appeared in the program's American run. In total, the Russian series added thirty-three episodes, comprising roughly one extra season. Some of the scripts for the new episodes were new while others came from scripts that were rejected by the American original (Levy, 2007). Sony also reassembled some of the writers who had worked on The Nanny and had them create new scripts that were localized in Russia. This fact is particularly notable, since extending a formatted show beyond the length of the original was uncommon for adaptations of scripted formats.

While the popularity of the series makes it a significant milestone in Russian television history, it was My Fair Nanny's role in domesticating the sitcom that ultimately made it an interesting object of study. The program began a phase of localized programs on STS, and its rival entertainment network, TNT, which came to include programs like Everybody Loves Raymond, Who's the Boss, Married with Children, and Grace Under Fire, as well as dozens of others. While not all of these programs were as successful as $M y$ Lovely Nanny, the genre as a whole became very popular. Despite high ratings, the extensive use of formatted shows would eventually cause problems for STS. The Russian station had to pay a licensing fee to the rights holders for every episode produced, and the fact that they did not fully own the rights to the programs limited the avenues for monetizing their most popular products. All the original scripts created for the Russian version of The 
Nanny, for example, remained the property of Sony Television rather than STS. In addition, the revenue from any sales of the show to proxy markets like Ukraine would have to be shared with Sony. Ultimately, this localization phase and the problems of using a format owned by a global company would lead STS to try creating its original series that it would own and control outright.

\section{Making a Russian Sitcom or Making the Sitcom Russian?}

In September 2007, STS premiered a program called Papiny Dochki (Dad$d y$ 's Girls) (Murugov, 2007). The series was the first original Russian sitcom to gain genuine popularity. It would eventually run for four hundred and ten episodes before ending in early 2013. At its high point in 2008, the series garnered a twenty-one percent share of the Russian ratings, meaning that about one out of every five Russian viewers tuned in four times a week ("Daddy's Girl's Returns to Television with Film Cliches," 2012). The series follows the exploits of the Vasnetsov family that, at least initially, is made up of the father Sergei and his five daughters: Masha, Dasha, Zhenya, Galina, and Paulina. When the audience meets the family, the girls' mother Lyudmila has just left them to emigrate to Canada with a hockey player with whom she was having an affair. At the beginning of the series, each of girls represents a different cultural niche: Masha is trendy, Dasha is goth, Zhenya is sporty, Galina is brainy, and Paulina is a cute young child. Other characters include the girls' grandmother, the teachers at the girls' school, Sergei's philandering friend Antonov and his lazy, incompetent office assistant. The series' humor revolves around the daily lives of the girls and their father. Most of the plots focus on problems at school, with boys and the frequent interfamily squabbles that result from five girls occupying a two-bedroom apartment. The father is mostly the butt of jokes regarding his incompetence as a family therapist, the most notable being the dissolution of his marriage. The series' focus on finding the humor in daily life makes it a fairly typical sitcom.

Daddy's Girls represents the second phase of interaction with the global cultural economy, which is referred to as hybridization. Marwan Kraidy's 
(2005) interpretation of the concept suggests that hybridity is one of the key cultural processes of globalization. Essentially, according to Kraidy, hybridity exists when a text enters a foreign culture and is transformed by blending with elements of a local culture. Kraidy (2005) further suggests that hybridity "repudiates the idea that cultures are discrete and separate entities, historically unchanging wholes into which birth alone secures membership" (Kraidy, 2005, p. 161). Instead, he proposes that cultures are constantly flowing in and out of each other, leaving elements behind, and that the speed and intensity of this process have increased exponentially in the era of globalization. We can, therefore, see Daddy's Girls as an example of hybridity because it takes the form of the western sitcom and makes a Russian example of that genre that does not draw explicitly from any existing program. It is instead, a Russian sitcom that mixes a global genre and Russian particularities. Because this series, and My Fair Nanny before it, are the products of cultural industries, they should be understood as forms of intentional hybridity. The concept comes from the work of Mikhail Bakhtin (1982) who suggests that in intentional hybrid "two socio-linguistic consciousness ... come together and consciously fight it out," adding that "it is the collision between differing points of view on the world that are embedded in these forms" (p. 360). This type of cultural transaction is properly understood as hybridity rather than convergence because it is directed by industrial concerns rather than being participatory (Uribe-Jongbloed \& Espinosa-Medina, 2014). Whereas My Fair Nanny is a form of cultural hybridity that is more akin to the translation than an actual collision, Daddy's Girls represents a much more complete form of intentional hybridity. The latter merges the cultural expectations of Russian audience and tells Russian stories rather than globally adaptable ones but within the accepted norms of the global sitcom. This hybridization is not, however, the result of a passive process but is instead the result of the work of Russian creative industry workers and is, therefore, a conscious, intentional process.

STS translated the success of the series into several other ventures, and it remains, to this date, one of the most comprehensive efforts ever undertaken by a Russian television company to generate other sources of revenue from a piece of intellectual property. The network licensed the sale of 
merchandise based on the series, covering a substantial range of products including notebooks, sticker albums, kitchenware, apparel, book bags, and a series of novels. Even more significantly, STS produced two video games based on the series. These games were initially designed to run on Windows-based PCs but eventually were adapted for phones and tablets running Google's Android operating system, as well as a web-based version of the second game, which was playable via the Russian social networking site Vkontakte.

Daddy's Girls served as a proof of concept that original Russian sitcoms could be a profitable venture for television producers. Following the success of the program, an increasing number of new Russian sitcoms began to appear. While several of STS' original sitcoms have run more than a hundred episodes, many of the most successful examples of the genre were produced by rival network TNT. Programs like Univer (University), Interni (Interns) and Deffchonki (Girls) have enjoyed long runs and at times dominated the ratings in their timeslots. That all of these successful programs appeared only after Daddy's Girls proved that it was possible to make a massively popular original Russian sitcom, speaks to that series' importance to the history of television in Russia.

Another reason the series is important to understand the history of Russian television is its sale as a format to the German television station Das Vierte. Presumably, the German network was drawn to the series because of the success it had enjoyed in the Russian market. The adapted program, called $A$ House Full of Daughters, was a commercial and popular failure, and the German company produced only a single thirty-five episode season though more than two-hundred scripts were available at the time. Critics panned the series as being amateurish, and they complained about several issues related to the series, the most prominent of which were the shallow character development and extensive use of stereotypes. Another problem was the use of the laugh track, which German audiences apparently found as painfully inappropriate as early post-Soviet Russians (Schluter, 2010). Critics also noted that the scripts were poorly localized, and the humor and situations seemed too Russian (Schluter, 2010). These critiques and the failure of the program 
was a major setback for STS and the Russian television industry in general, but it also marked a significant milestone for the station and gave it an opportunity to learn about how to make a program that could also appeal globally. This example is especially notable because producing exportable programming is an aspect of the television business with which Russian companies have little experience. Excluding Daddy's Girls, only three other shows had ever been exported from Russia. Sony Television produced a variant of TNT's reality show Dom-2 in Mexico. The animated cartoon Smeshariki aired on the American network, The CW, under the title GoGoriki, and another animated cartoon, Masha i Medved (Masha and the Bear), is available on the streaming site Netflix (Kitayeva, 2013).

Regardless of the results, the attempt to adapt Daddy's Girls serves to illustrate both the ambition and the importance of STS and the series it finances to the overall Russian television landscape. With Daddy's Girls, STS created an original Russian sitcom, grew it into a multiplatform transmedia property and then sold the program as a format, albeit relatively unsuccessfully. This program and the surrounding transmedia products created by STS all mark significant firsts for the Russian television industry. As STS continued its growth as an international brand, the lessons it learned from the successes and failures of Daddy's Girls led to a shift in its overall strategy, especially with regards to the construction of future series.

\section{The Odorless Kitchen}

The final program that marks STS' movement toward being the producer of not only original Russian programming but also programs that appeal to and sell in the global marketplace is Kukhnia (The Kitchen) (Murugov, 2012). As noted above, Russian programs are not often sold in the global marketplace, and this is no doubt due to the production of series with a narrowly national appeal. Sales of Russian programs that are later voiced over or subtitled certainly exist, but are typically limited to culturally proximate countries like Ukraine, Belarus, and Kazakhstan (Straubhaar, 1991). For the most part, Russian series, particularly police procedurals or military dramas, are so culturally specific that they do not even appear outside of Russia. Russian comedies and melodramas have drawn some interest, 
but they are still shown mostly in countries with large Russian-speaking minorities and lack global appeal.

As part of a rebranding effort that began in 2011, STS began working on a program that would be both a success in Russia and have the kind of global appeal that had evaded Russian producers until that time. The Kitchen appeared at a moment when STS was beginning to give up the ratings lead that it had built up over rival networks, particularly over Gazprom-media holdings' TNT, which had essentially come to prominence by copying STS' programming strategy. ${ }^{3}$ By spring of 2011, STS' television properties (particularly Daddy's Girls) were failing to draw significant audiences. The company needed a new hit show and overall strategy to differentiate itself from its increasingly aggressive and popular rival. The new strategy was to produce higher quality programs, particularly with regards to visuals and programs with a broad appeal that might be marketable at trade fairs like MIPCOM and MIPTV. With this goal in mind, STS reorganized its two in-house production units (Costafilm and Soho Media) into a single unit, Story First Productions, and began upgrading the new firm's production facilities ("CTC Media creates united production company Story First Production," 2011). As a result, the reorganized unit produced no new series in 2012 or the first half of 2013. To make up for the shortfall in their inhouse capabilities, STS contracted a large percentage of their productions to third party studio Yellow, Black, and White with whom STS' general director Vyacheslav Murugov had a prior relationship. This firm took over the production of many STS shows, most notably Daddy's Girls, which was retooled into an hour-long format and shifted from sitcom to dramedy while also receiving a substantial boost in its production values.

The Kitchen was the first new program born from the partnership between STS and Yellow, Black and White and is notable in several ways. It has the highest budget of any Russian sitcom ever produced at approximately two hundred thousand dollars per episode. For those familiar with the high costs of American and other Western television industries, this

3 STS and TNT have been described roughly as the Coke and Pepsi of the Russian television landscape, in that their program offering is for all intents and purposes identical. 
might not seem like a particularly large budget, but by Russian standards, it is very significant. The upgraded budget for the show allowed them to produce a program that in many ways is visually comparable with Western, single camera situation comedies. The strategy creating high-quality programs was successful and, through the first three seasons, The Kitchen was a ratings success, winning its time slot and helping to reinvigorate the STS brand as a whole ("The Kitchen on STS is the nation's favorite," 2012). The finale of the third season set an all-time ratings record for a Russian series, attracting about thirty percent of viewers in Moscow and twenty-five percent in the rest of the country ("Third Season of The Kitchen End with Record Ratings," 2014). A film based on the series called Kukhnia v Parizhye (The Kitchen in Paris) meant to bridge the gap between the third and fourth seasons of the show dominated the Russian box office for two weeks following its release and earned over four times its production budget. This profitable theatrical run is a major achievement for a Russian film since they regularly fail to recoup the money invested and have to rely on state funding to break even ("Russian Box Office: The Kitchen in Paris Leads Again," 2014). The success of the film led the network to announce that they would produce a second film, tentatively titled The Kitchen in China for fall 2016 ("Sequel to the Kitchen in Paris to be Set in China," 2014).

In that it is a very popular Russian series, The Kitchen is significant on its own. However, the structure of the series points to STS' strategy going forward. In particular, it shows how the network intends to create programs that could help it become a provider of premium content outside of Russia. The Kitchen is built to be exported easily as both a subtitled or voiced-over program, or even more significantly as a format. The series excludes most of the significant cultural markers that would ultimately have signaled it as being specifically Russian. This removal of makers makes the program "culturally odorless." The concept of "cultural odor" was originally proposed by Koichi Iwabuchi (2002) in his discussions of the Japanese cultural industry. Reduced to its basic form, Iwabuchi suggests that Japanese producers have long created cultural texts that are easily exported, by making sure that cultural markers that would signal the series as being Japanese, which he calls cultural odor, are removed (Iwabuchi, 2004). He de- 
fines cultural odor as the elements that tie a cultural product "with widely disseminated symbolic images of the country of origin" (Iwabuchi, 2002, p. 38), often in a way that can be disconcerting to global audiences. To avoid being too rigidly tied to the culture of their homeland and therefore unacceptable to global audiences, Japanese animators often draw characters that do not look Japanese, a style they call mukokuseki (Iwabuchi, 2004). It is this type of approach, that is, removing Russian cultural odor, that Yellow, Black and White and STS employed to make The Kitchen more exportable.

The setting is the most important aspect of this cultural odorlessness. The series takes place in an upscale French Restaurant called Claude Monet, and though it obviously takes place in Moscow, it could easily be transposed into any global city, from New York to Beijing. The design of the sets is fairly generic, mostly consisting of high-end furniture with a bar at the back. The kitchen at the restaurant is industrial in its appearance, with white tiles and professional-grade kitchen equipment. The only significant cultural markers that appear in the restaurant are the head chef's fan paraphernalia for his favorite sports club, FC Spartak Moscow. As part of the localization of the program, these items could easily be changed to match the new context.

The series' most striking removal of Russian cultural odor, however, is its use of non-diegetic music. Typically, Russian series that use music as theme songs or non-diegetically have licensed it from Russian artists. This practice is probably related to costs since licensing music from Russian artists is less expensive than doing so from well-known western bands. Daddy's Girls, for example, used music from Moscow-based band Uma2urman as a theme song, while another popular series, Margosha, used a song from the Russian group Mummy Troll. The Kitchen, for its part, uses music almost exclusively from the cannon of global music. Most prominently, the program features music from Beyoncé, Neon Trees, Enya and OK GO, but virtually all the music used in the series is taken from a host of English-speaking artists both, well known and obscure, or the library of classical music. In fact, through the first sixty episodes of the series, non-diegetic Russian music is used in only three instances. Thus, the music used in the show is already familiar to global audiences, adding to the series' odorlessness. 
Most of the humor in the series revolves specifically around the conflicts that take place in the restaurant or related to the romantic misadventures of the series' philandering protagonist, Max Lavrov. The restaurant portion of the humor often has to do with the problems that emerge from the head chef's alcoholism and gambling addictions, which often undermine the work that goes on in the kitchen as different kitchen staff members scramble to cover up their leader's shortcomings. Some comic situations also arise from the competition of the head chef with his counterpart at a newly opened, competing, high-end restaurant on the same block. Most often, these situations, like reporting the neighboring restaurant for immigration violations, backfire and end up embroiling the Claude Monet restaurant as well. For this situation, in particular, it is easy to imagine a similar situation taking place in a restaurant in New York but with Central American rather than Central Asian migrants. The problems of illegal immigrants and the government's efforts to regulate their presence represent a theme that is universal in developed countries. The series builds its humor on these types of universal situations.

It is notable that very little of the humor involves any interaction with Russian institutions in a way that would be hard to adapt to a foreign situation. Where there are interactions with state institutions, they are fairly generic. For example, after the chef has a heart attack, he is forced to remain in the hospital and has to suffer through the horrors of hospital food-in this case, a Russian buckwheat porridge called kasha. His efforts to save himself by ordering pizza using his mobile phone are repeatedly thwarted by the gruff head nurse who confiscates the pizza, while still forcing her patient to pay. It is safe to say that suffering through bad hospital food constitutes a more or less universal experience.

The most important Russian institutions, the police and security apparatus, rarely appear in the series. In fact, excluding the film, the series has only two major interactions with the police. In one instance, Max, the series' protagonist, runs afoul of a police officer whose wife has taken an interest in him. While the couple eats at the restaurant, the police officer catches his wife with Max, who has been unwillingly pulled into 
the bathroom, and proceeds to fire his weapon repeatedly at the young cook, who survives by taking refuge behind the bar. Again, this situation seems to be one that is universally funny and would not be difficult for a Western audience to understand. The second encounter occurs after the chef, seeking refuge from the dreaded hospital food, escapes out the window in his hospital gown to purchase a hot dog in a local park. The police mistake him for a mental patient since he is sitting on a bench in a hospital gown eating a hotdog in the middle of a Moscow winter. The only other moment where the series' protagonists encounter a state official is when they are forced to bribe a health inspector who annually threatens to shut down the restaurant. Their interaction, presented in the form of flashbacks, show the inspector noticing health and safety infractions in the kitchen and being bribed to overlook them. The humor in this situation comes from the fact that the infractions that he is bribed to overlook often involve moving a fire extinguisher from one place and then moving it back the next year. While corruption is endemic to Russia in a way that it is not in many other places, a corrupt health inspector extracting bribes is not so unique to that country that it would be hard to translate to a non-Russian context. While these examples are hardly exhaustive, they do show the care taken in crafting comic situations that are not too specifically Russian and to exclude those that would be difficult for a global audience to grasp. This tactic ultimately leads to a cultural product that, excluding the fact that all dialogue is in Russian, does not bear many traces of Russia.

\section{Conclusion}

The strategy of creating culturally odorless texts was apparently successful, since on November 26, 2013, Yellow, Black and White's distribution company All Media announced that it had reached an agreement with the international distribution arm of American network CBS to sell The Kitchen worldwide (Kitayeva, 2013). The deal leaves the former Soviet republics under the control of STS and Yellow, Black and White but allows CBS to use the series' format to create an adaptation in all the markets outside of that zone, excluding Israel. Obviously, this is a very important agreement 
from the Russian point of view. Thus far, three adaptations of the program have appeared in Georgia, Estonia, and Greece. Given that those countries have cultural ties to Russia, it is not altogether clear that this represents a true success on the global stage. The series was also sold as a subtitled product to the internet streaming sites Hulu and Amazon Prime, though it is again unclear how the series has performed (Osberg, 2015). While the global success of The Kitchen remains somewhat unclear, this has not stopped STS and Yellow, Black and White from pushing forwards with further efforts to develop programs for the global marketplace. It is still unclear how the program will perform globally and whether building series for export is the beginning of a trend in Russian sitcoms. What is clear is that, led by STS, the Russian television industry has been learning how to create sitcoms that appeal to a broad audience. While Russian companies are still net buyers of television products, the fact that STS has begun to try to sell programs like Daddy's Girls and The Kitchen outside Russia suggests that the focus of the Russian television industry may be shifting in significant ways. As the Russian market continues to mature and competition increases, Russian companies will need to seek other ways to monetize their intellectual property. STS has always been a leader in the production of foreign genres in Russia, and they seem to have turned their international orientation towards crafting products to sell on the global market. With Daddy's Girls, this was a secondary consideration and began only after the series had already succeeded in the Russian market. Essentially, this led to the series being problematic for adaptation. For The Kitchen, foreign sales as a canned program and as a format are part of the program's very nature. This shift suggests that Russian producers are looking to create programs aimed at the global market that can first regain their development costs in Russia. Though one series does not make a trend, it certainly suggests that Russian companies are seeking to broaden the way that they monetize their intellectual property. Russia now has a template to follow in order to create a global-ready series. If STS succeeds in making The Kitchen into a successful global sitcom, it follows that other Russian producers will start targeting their products at the global market as well. If that happens, Russia will return to the place of cultural prominence that it has not enjoyed since the end of the Cold War. 


\section{References}

Bakhtin, M. M. (1982). The dialogic imagination: Four essays. (M. Holquist \& V. Liapunov, Eds., V. Liapunov \& K. Brostrom, Trans.). Houston: University of Texas Press.

CTC media creates united production company Story First Production. (2011, July 28). Retrieved from http://www.ctcmedia.ru/presscenter/releases/?id=882\#.U-KU90iKUhM

Heller, D. (2003). Russian "sitkom" adaptation: The pushkin principle. Journal of Popular Film and Television, 31(2), 60-72.

History of CTC. (n.d.). Retrieved from http://www.ctcmedia.ru/about/ history/

Hutchings, S. C. \& Rulyova, N. (2009). Television and culture in Putin's Russia. New York: Routledge.

Iwabuchi, K. (2002). Recentering globalization: Popular culture and Japanese transnationalism. Durham: Duke University Press.

Iwabuchi, K. (2004). How "Japanese" is Pokemon. In J. J. Tobin (Ed.), Pikachu's global adventure: The rise and fall of Pokémon (pp. 53-77). Durham: Duke University Press.

Kitayeva, K. (2013, November 26). Russkaya Kukhnya dlya Amerikantsev [Russia's The Kitchen for Americans]. Retrieved from http://rbcdaily.ru/media/562949989726542

Kraidy, M. (2005). Hybridity: The cultural logic of globalization. Philidelphia: Temple University Press.

Kukhnya na STS Ponravilas Strane [The Kitchen on STS is the nation's favorite]. (2012, October 25). Retrieved from http://www.varietyrussia.com/film/25-10-2012/kukhnya-na-sts-ponravilas-strane/ 
Levy, C. J. (2007, September 10). Still married, with children, but in Russian. The New York Times. Retrieved from http://www.nytimes. com/2007/09/10/world/europe/10sitcom.html

Moran, A. (1998). Copycat television: Globalisation, program formats and cultural identity. Bloomington: Indiana University Press.

Murugov, V. (Producer). (2007). Papiny Dochki [Television series]. Moscow: STS.

Murugov, V. (Producer). (2012). Kukhnia [Television series]. Moscow: STS.

Osberg, M. (2015, January9). Planet TV: In Russia, TVWatches You. The Verge. Retrieved from http://www.theverge.com/2015/1/9/7517419/ russian-television-review-planet-tv

Papiny Dochki Vernutsya Na Tv S Kino Klishe [Daddy's Girl's returns to television with film clichés]. (2012, May 6). Retrieved from http:// www.varietyrussia.com/tv/05-06-2012/papiny-dochki-vernutsya-na-tv-s-kino-klishe/

Prokhorova, E. (2010). Flushing out the Soviet: Common places, global genres and modernization in Russian television serial productions. Russian Journal of Communication, 3(4), 185-204.

Rodnyansky, A. (Producer). (2004). Moia Prekrasnaia Niania [Television series]. Moscow: STS.

Rossiyskiy Prokat: Kukhnya v Parizhe Vnov Lidiruet [Russian box office: The Kitchen in Paris leads again]. (2014, May 12). Retrieved from http://www.varietyrussia.com/film/12-05-2014/rossiyskiyprokat-kukhnya-v-parizhe-vnov-lidiruet/

Roth-Ey, K. (2011). Moscow prime time: How the Soviet Union built the media empire that lost the cultural Cold War. Ithaca: Cornell University Press. 
Schluter, J. (2010, August 18). Ein Haus voller Töchter oder: Schlimmer geht's nimmer [A House full of Daughters: It could not possibly get any worse]. Retrieved from http://www.quotenmeter.de/n/43946/einhaus-voller-toechter-oder-schlimmer-geht-s-nimmer

Sikvel Kukhni v Parizhe Otpravitsya v Kitay [Sequel to The Kitchen in Paris to be set in China]. (2014, May 27). Retrieved from http:// www.varietyrussia.com/tv/27-05-2014/sikvel-kukhni-v-parizheotpravitsya-v-kitay/

Straubhaar, J. D. (1991). Beyond media imperialism: Assymetrical interdependence and cultural proximity. Critical Studies in Mass Communication, 8(1), 39-59.

Tapinas, A. (2014, August 6). In bed with Kremlin. Retrieved from http:// www.tapinas.lt/2014/08/in-bed-with-kremlin/

Tretiy Sezon Kukhni Zavershilsya s Rekordnymi Reytingami [Third season of The Kitchen end with record ratings]. (2014, April 4). Retrieved from http://www.varietyrussia.com/tv/04-04-2014/tretiysezon-kukhni-zavershilsya-s-rekordnymi-reytingami/

Uribe-Jongbloed, E. \& Espinosa-Medina, H. D. (2014). A clearer picture: Towards a new framework for the study of cultural transduction in audiovisual market trades. OBSERVATORIO $\left(\mathrm{OBS}^{*}\right), 8(1), 23-48$. 